\title{
ESTIMATION OF MOST PROBABLE NUMBER OF SALMONELLA IN MINCED PORK SAMPLES
}

\author{
Luciane Martins Borowsky; Verônica Schmidt; Marisa Cardoso*
}

Departamento de Medicina Veterinária Preventiva, Universidade Federal do Rio Grande do Sul, Porto Alegre, RS, Brasil

Submitted: July 24, 2006; Returned to authors for corrections: November 30, 2006; Approved: July 18, 2007.

\begin{abstract}
The quantification of microorganisms present in food samples is an important step to assess the risk to consumers. The number of salmonellae in 20 positive samples of minced pork was determined by the Most Probable Number method. Counts ranging between $<3$ and $240 \mathrm{cfu}^{-1} \mathrm{~g}^{-1}$ were found in the analyzed samples.
\end{abstract}

Key words: Salmonella sp., MPN, minced pork

Salmonella sp. is one of the most important contaminants of food products and an important cause of food borne disease in many countries $(10,12)$. In Brazil, most salmonellosis outbreaks have been related to the consumption of eggs or salad prepared with homemade mayonnaise $(5,11)$. Of 75 food samples involved in salmonellosis outbreaks in the State of Rio Grande do Sul between 1999 and 2000, only four were pork products (11). In contrast, studies carried out in the same region reported a high prevalence of Salmonella on pig farms, at slaughter and in pork $(3,4)$. For this reason, it is important to evaluate the risk which pork products pose to consumers. According to the Codex Alimentarius, risk analysis includes hazard identification and quantification (14). Currently, food samples are submitted to methods for detection of Salmonella, but quantification protocols are not routinely used in food microbiology. Thus, the aim of this study was to enumerate salmonellae in samples of minced pork used for fresh sausages production in slaughterhouses in Southern Brazil.

Two previous studies $(6,8)$ have used Most Probable Number (MPN) methods to estimate the number of Salmonella in naturally contaminated food samples, but adapted different protocols for sample preparation: rinsing or homogenization of the food sample, respectively. Therefore, we first compared the two methods in artificially contaminated pork samples. Raw pork sausage samples were obtained from supermarkets in Porto Alegre, Brazil, and submitted to a screening for Salmonella as previously described (13). Only Salmonellanegative samples were included in the study. Portions $(25 \mathrm{~g})$ of raw minced pork removed from the sausages were spiked with $10^{1}, 10^{2}$ or $10^{3} \mathrm{cfu}^{-1} \mathrm{~g}^{-1}$ of Salmonella Typhimurium ATCC14028 or two strains of $S$. Typhimurium (ST1 and ST2) isolated from pork in Southern Brazil. Spiked samples were then submitted to Salmonella quantification, using method A (6) and method B (8). In method A, each artificially inoculated sample was rinsed with $225 \mathrm{~mL}$ of buffered peptone water (BPW) and the rinsing fluid was divided into three aliquots of $50 \mathrm{~mL}, 5 \mathrm{~mL}$ and $0.5 \mathrm{~mL}$. The three $0.5 \mathrm{~mL}$-aliquots were added to three $5 \mathrm{~mL}$ fresh BPW. In method B, triplicate tubes for each of the three dilutions were used. The first decimal dilution $\left(10^{-1}\right)$ was prepared by adding a 25 -g portion of contaminated pork sausage, prepared as described above, to $225 \mathrm{~mL}$ of BPW. After homogenization of the mixture, subsequent dilutions $\left(10^{-2}\right.$ and $\left.10^{-3}\right)$ were prepared in BPW. In both methods, the BPW aliquots were submitted to pre-enrichment at $37^{\circ} \mathrm{C}$ for $18 \mathrm{~h}$, and a $0.1 \mathrm{~mL}$ volume of each pre-enrichment tube was subcultured to $9.9 \mathrm{~mL}$ of Rappaport-Vassiliadis Broth (Merck). After incubation at $42^{\circ} \mathrm{C}$ for $24 \mathrm{~h}$, aliquots of the broth were streaked onto Xylose-Lysine-Tergitol 4 Agar plates (XLT4, Merck). After a $24 \mathrm{~h}$ incubation at $37^{\circ} \mathrm{C}$, suspected colonies were picked, tested for agglutination using polyvalent $\mathrm{O}$ antiserum (Probac do Brasil - Produtos Bacteriológicos Ltda, São Paulo, Brazil) and confirmed by biochemical tests. The number of Salmonella-positive plates in each dilution was used to calculate the Most Probable Number (MPN) of Salmonella in the inoculated pork sausage samples, using MPN tables (1,7).

*Corresponding Author. Mailing address: Departamento de Medicina Veterinária Preventiva, UFRGS. Av. Bento Gonçalves, 9090. 90450-000, Porto Alegre, RS. Tel.: (+5551) 3308-6123 - Fax: (+5551) 3308-7305. E-mail: mcardoso@ufrgs.br 
Thirty samples (200 g) of minced pork used in pork sausage production were collected at abattoirs in southern Brazil. A 25$\mathrm{g}$ portion of each sample was submitted to Salmonella isolation as previously described (13), whereas the remaining samples were stored at $-18^{\circ} \mathrm{C}$ for up to 90 days. Positive samples were submitted to method A and method B of Salmonella quantification as previously described.

From a total of 45 artificially inoculated samples analyzed by the two methods, MPN values ( $95 \%$ confidence interval) were in accordance with the amount (cfu. $\mathrm{g}^{-1}$ ) of Salmonella inoculated in 38 and 41 samples analyzed by methods A and B, respectively. No statistically significant differences $(\mathrm{P}=0.5216)$ were found between the agreement of MPN classes determined by either method A or method B considering the amount of Salmonella inoculated in the pork sausage samples.

In previous studies, both methods were considered effective for enumeration of Salmonella in naturally contaminated foods $(6,8)$, but variations in the distribution pattern of the frequencies within MPN classes obtained from a single sample analyzed by different laboratories in a ring-trial were reported (15). Variations were explained by the low number of Salmonella in pork and by the heterogeneous distribution of microorganisms on solid foods (15).

Salmonella was isolated from 28 (93.3\%) minced pork samples collected from abattoirs. Twenty Salmonella positive minced pork samples submitted to both MPN protocols presented counts ranging between $<3$ and $240 \mathrm{cfu}^{-1} \mathrm{~g}^{-1}$ (Table 1). In 12 samples Salmonella counts were below the detection limit of both methods. Freezing probably caused cell stress and reduced the number of viable cells to a not-detectable level. A progressive decrease of cell viability were reported in raw pork and frozen meat $(2,9)$. In a previous study, Salmonella counts in artificially inoculated minced pork were also reduced after a period of 180 days of frozen storage (15).

Table 1. Most Probable Number of Salmonella sp. determined by methods A and B in minced pork samples $(n=20)$ collected in abattoirs in southern Brazil.

\begin{tabular}{ccc}
\hline \multirow{2}{*}{ Number of samples } & \multicolumn{2}{c}{ MPN Salmonella $\left(\right.$ cfu.g $\left.^{-1}\right)$} \\
\cline { 2 - 3 } & MethodA & Method B \\
\hline 12 & $<0.3$ & $<3$ \\
2 & 0.92 & $<3$ \\
1 & 1.1 & $<3$ \\
1 & 1.5 & 9.2 \\
1 & 2.8 & 15 \\
1 & 3.6 & $<3$ \\
1 & 9.3 & 9.2 \\
1 & $>110$ & 240 \\
\hline
\end{tabular}

The high number of minced pork samples positive for Salmonella observed in this study is in accordance with previously reported results. In Germany, $73.3 \%$ of minced pork samples were positive for Salmonella (15), while Salmonella could be isolated from $91.8 \%$ of raw pork samples taken from butcher shops in Mexico (8). In both cases and in the present study, estimated MPN values were low $(<100 \mathrm{~g})$.

The low number of salmonellosis outbreaks related to pork in Southern Brazil might be explained by the low Salmonella counts reported for these products and by the fact that pork is traditionally eaten well-done in this region. On the other hand, cross-contamination of ready-to-eat products directly via raw pork or indirectly via contaminated kitchen surfaces may represent a potential health hazard. Further studies evaluating the contamination level of pork sausages at the retail level and in food samples involved in salmonellosis outbreaks in southern Brazil might contribute to a better estimation of the hazard that pork might pose to consumers in this region.

\section{ACKNOWLEDGEMENTS}

This work was supported by Conselho Nacional de Desenvolvimento Científico e Tecnológico (CNPq) scholarship.

\section{RESUMO}

\section{Estimativa do número mais provável de Salmonella sp. em amostras de carne suína moída}

A identificação de risco inclui uma etapa de quantificação do microrganismo no produto avaliado. O número de Salmonella sp. em 20 amostras de carne suína moída previamente identificadas como positivas foi determinado pelo método do

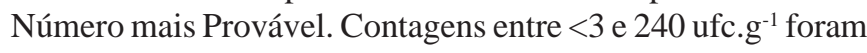
encontradas nas amostras analisadas.

Palavras-chave: Salmonella sp., carne suína, NMP

\section{REFERENCES}

1. BAM. Bacteriological Analytical Manual. Online. (1998). Appendix 2: Most Probable Number Determination from Serial Dilutions. Ed. 8 , revision A.

2. Barrel, R.A.E. (1988). The survival and recovery of Salmonella Typhimurium phage type U285 in frozen meats and tryptone soya yeast extract broth. Int. J. Food Microbiol., 6, 309-316.

3. Bessa, M.C.; Costa M.; Cardoso M. (2004). Prevalência de Salmonella sp. em suínos abatidos em frigoríficos sob inspeção federal no Rio Grande do Sul. Braz. J. Vet. Res., 24, 80-84.

4. Castagna S.M.F.; Schwarz, P.; Canal, C.W.; Cardoso M. (2004). Prevalência de suínos portadores de Salmonella sp. ao abate e contaminação de embutidos tipo frescal. Acta Scient. Vet., 32, 141147.

5. Costalunga, S.; Tondo, E.C. (2002). Salmonellosis in Rio Grande do Sul, Brasil, 1997 to 1999. Braz. J. Microbiol. 33, 342-346. 
6. Dufrenne, J.; Ritmeester, V.; Van Asch, E.D.; Van Leusden, F.; de Jonge, R. (2001). Quantification of the Contamination of Chicken and Chicken Products in the Netherlands whit Salmonella and Campylobacter. J. Food Prot., 64, 538-541.

7. de Man, J.C. (1983). MPN tables, corrected. Eur. J. Appl. Microbiol., 17:301-305.

8. Escartín, E.F.; Lozano, J.S.; Rodriguez, O.; Gonzales, N.M.; Torres, J.A. (1995). Incidence and level of Salmonella serovars in raw pork obtained from Mexican butcher shops. Food Microbiol., 12, 435-439.

9. Escartín, E.F.; Lozano, J.S.; Garcia, O.R. (2000). Quantitative survival of native Salmonella serovars during storage of frozen raw pork. Int. J. Food Microbiol., 54, 19-25.

10. European Commission. (2000). Opinion of the Scientific Committee on veterinary measures relating to public health on food-borne zoonoses (p.183). Brussels: Directorate B-Scientific Health Opinions.Nit europa.eu.int/comm/food/fs/sc/sc/out32_en.pdf.
11. Geimba, M.P.; Tondo, E.C.; Oliveira, F.A.; Canal, C.W.; Brandelli, A. (2004). Serological characterization and prevalence of $s p v \mathrm{R}$ genes in Salmonella isolated from foods involved in outbreaks in Brazil. $J$. Food Prot., 67, 1229-1233.

12. Mead, P.S.; Slutsker, L.; Dietz, V.; McCaig, L.F.; Bresee, J.S.; Shapiro, C.; Griffin, P.M.; Tauxe, R.V. (1999). Food-related illness and death in the United States. Emerging Infect. Dis., 5, 607-625.

13. Michael, G.B.; Simoneti R.; Costa M.; Cardoso M. (2003). Comparison of different selective enrichment steps to isolate Salmonella sp. from feces of finishing swine. Braz. J. Microbiol., 34, 138-142.

14. Oscar, T.P. (2004) A quantitative risk assessment model for Salmonella and whole chickens. Int. J. Food Microbiol., 93, 231-247.

15. Sinell, H.J.; Pietzsch, O.; Klingbell, H.; Benner, M. (1990). Estimation of most probable number of Salmonella in retail samples of minced pork. Int. J. Food Microbiol., 11, 135-142. 